\title{
Procesy evropské defragmentace jako inspirativní nástroj policymaking
}

\author{
Tomáš Váňa ${ }^{1}$
}

\begin{abstract}
Text vznikl v rámci projektu Specifického vysokoškolského výzkumu SVV 2012265502 Problémy legitimity politického rozhodování na počátku 21. století na UK, FSV, IPS.
\end{abstract}

\begin{abstract}
Processes of European Defragmentation as an Inspirative Tool for Policymaking
This paper looks at the different stages of European municipal defragmentation and at the diverse models that post-war countries have adopted for their municipal structures. It notes that defragmentation has been undertaken with little previous knowledge regarding the possible impacts of these approaches. Through applying the QCA method of analysis it looks at common and distinct features of these approaches and draws a sharp dichotomy between defragmentation trends in post-communist countries and countries of the Western bloc. By showing that there are trends intrinsic to post-communist political systems, this paper presents the idea that these systems can learn from errors made by countries that approached municipal defragmentation before them. Drawing on the example of the late-defragmenting Iceland, this paper shows how currently or prospectively defragmenting countries can learn from its experience. In the last part of the paper, suggestions are made with regard to how the Czech Republic can learn from this experience, particularly from democratic referendums, legislative and economic incentives, and municipal cooperation.
\end{abstract}

Kywords: Defragmentation; Iceland; municipality; self-government

\section{1. Úvod}

Defragmentační procesy pozorovatelné v Evropě od poloviny 20. století byly prrirozeným důsledkem snahy o obnovu válkou zničeného kontinentu a o zlepšení výkonu vlády na úrovni obcí. Procesy modernizace a technologické inovace, nárůst komplexnosti agendy místních samospráv, prohlubování sociálního státu (zejména ve Skandinávii) v souladu s Beveridgovou koncepcí welfare state (Beveridge 1942), úsilí o ekonomickou efektivitu a úspěšné plnění státní role na lokální úrovni, to vše byly důvody, proč lze v řadě zemí poválečné Evropy pozorovat procesy narůstající meziobecní spolupráce, která nezř́íka přerostla do procesů slučování obcí a postupné defragmentace obecních struktur (Baldersheim, Stahlberg c1994: 10).

Tento text pojednává o vybraných aspektech evropské municipální defragmentace. Prostřednictvím metody QCA analyzuje vybrané evropské země a poukazuje na skutečnost, že na municipální defragmentaci je př́inosné pohlížet nejen z hlediska jejího legislativního, identitního či ekonomického uchopení, ale i uchopení časového. Na základě primárně časové proměnné, tedy období, kdy dané země defragmentovaly svou municipální strukturu, tento text rozlišuje a) země, ve kterých defragmentace proběhla $\mathrm{v}$ prvotním období, b) země, $\mathrm{v}$ nichž defragmentace proběhla $\mathrm{v}$ relativně aktuální době, c) země, $\mathrm{v}$ nichž defragmentace proběhla jak v druhé polovině 20. století, tak v relativně aktuální době, d) země, $\mathrm{v}$ nichž defragmentace neproběhla, e)

\footnotetext{
${ }^{1}$ PhDr. Mgr. Tomáš Váňa, M.A. Autor je interním doktorandem Katedry politologie na UK FSV IPS (U Kříže 8/661, Praha 5 - Jinonice). Zabývá se primárně teorií komunikace Karla Deutsche a problematikou efektivního vládnutí. Může být kontaktován na adrese vana@fsv.cuni.cz.
} 
postkomunistické země, které prošly v období komunismu procesem defragmentace a po přechodu k demokracii prošly opačným procesem opětné fragmentace, a f) postkomunistické země, které prošly v období komunismu procesem defragmentace a po přechodu k demokracii prošly opětným nebo pokračujícím procesem defragmentace a nedošlo u nich tedy k reverzní akci. Text se dále věnuje základním problémům zemí, které prošly defragmentací v polovině 20. století, a následkům této defragmentace a poukazuje na skutečnost, že země, které defragmentovaly relativně nedávno, měly vưči těmto zemím komparativní výhodu, nebot' se mohly poučit z jejich chyb. Text pracuje s dvěma zeměmi tohoto druhu, konkrétně Islandem a Německem. Dále se věnuje prŕpadu Islandu, rozebírá jeho proces defragmentace, poukazuje na jeho kladné stránky a konstatuje úspěšnou defragmentaci. Závěrečná část tohoto textu je věnována těm aspektům úspěšné islandské defragmentace, jimiž se mohou státy, u nichž lze tento proces očekávat, inspirovat. Konkrétně je poukázáno na př́lklad České republiky a prvky, které by do své očekávatelné defragmentace mohla přejmout. Text si tak klade za cíl shrnout problematiku evropské municipální defragmentace, poukázat na časový úhel pohledu na ni, rozeznat pozitivní defragmentační mechanismy a na základě zkoumání islandského případu navrhnout přejmutí několika jeho aspektů do České republiky.

\section{Trendy evropské defragmentace}

Vlna evropských municipálních defragmentací nebyla z časového ani prostorového hlediska jednotná. Ve Skandinávii docházelo ke slučování obcí od 50. do 90. let 20. století, zatímco ve státech středozápadní Evropy, především v Holandsku a Německu, ke slučování docházelo až od 60. a 70. let 20. století. Zcela ojedinělým př́kladem pozdního nastoupení trendu defragmentace je př́klad Islandu, $\mathrm{v}$ němž byla problematika defragmentace aktuální ještě na začátku třetího tisíciletí.

Z hlediska defragmentačního trendu $\mathrm{v}$ zemích bývalého Západního bloku představuje podnětný směr výzkumu opačný proces, který nastal v zemích Východního bloku, kde po jeho rozpadu došlo bud' k mírné (Jugoslávie, Polsko), či o poznání znatelnější fragmentaci (Mad’arsko, Česká republika, Slovensko) (Jüptner 2010). Odlišné trendy ve fragmentaci lze do značné míry připsat rozdílným ekonomicko-společenským trendům, které v Evropě nastaly po druhé světové válce. Zatímco v zemích Západního bloku probíhala defragmentace jako následek paradigmatické změny vnímání, kdy fragmentovaná obecní struktura byla přehodnocována jako ekonomicky neefektivní, avšak zároveň byly brány v potaz sociologické aspekty slučování obcí, v zemích Východního bloku byly následkem totalitárních ideologií zanedbávány společenské důsledky defragmentace, což vedlo $\mathrm{k}$ neprijímání těchto direktivně stanovených procesů a po pádech těchto režimů $\mathrm{k}$ opětné fragmentaci. Ukázalo se, že byt' je z ekonomického hlediska defragmentace obecních struktur prríznivá, pomíjení sociologických aspektů těchto procesů, především identifikace lokální populace s obcí, vlivu tradičních struktur, rodinných vazeb, lokálních elit a identit a kulturních proměnných, vede k nezvládnutí defragmentačních procesů a reverzním trendům, projevujícím se v pozdějším období (Klimovský 2010).

$\mathrm{V}$ souladu s výše řečeným je tak zásadní skutečnost, že důraz na identitní, kulturní, historickou a společenskou variabilitu je dnes v rámci Evropy (především ve strukturách Evropské unie) adekvátně akcentován. Trendy ke standardizaci, unifikaci a uniformizaci byly následkem poučení z vývoje ve Východním bloku opuštěny a nyní je podporován komplexní a harmonický rozvoj jednotlivých oblastí, v souladu s partikulárními potřebami jeho obyvatel, což 
je mimo jiné zakotveno v chartě Torremolinské a Aalborgské (CEMAT 1983, Aalborgská charta 1984).

Mezinárodně-vztažní antagonismy, geografická vzdálenost, kulturní rozdílnost, sociální odlišnosti a řada dalších faktorů přispívají $\mathrm{k}$ tomu, že nelze hovořit o jednotném modelu (de)fragmentace evropské obecní struktury. Zatímco řada zemí západní Evropy prošla defragmentací, lze mezi nimi nalézt i takové, u nichž se tento trend neprojevil, nebo projevil pouze v minimální míře. Mezi takové patř́i především Francie, ale také Švýcarsko, ze zemí jižní Evropy Itálie a Španělsko, a ze zemí stř̌ední Evropy Česká republika, Rakousko a Mad’arsko. Naopak ze zemí západní Evropy signifikantně defragmentovaly Belgie, Německo a Velká Británie, ze zemí jižní Evropy Řecko, a dále především skandinávské země (UCLG 2008: 133).

Zcela specifickou skupinu tvoři země, jež se po překonání bipolárního rozdělení světa vydaly opačnou cestu a následkem násilné defragmentace v období, kdy u nich vládly autoritativní či totalitární režimy, se po přechodu k demokracii, kontrárně k očekáváním a trendům v západní Evropě, vydaly cestou opětné fragmentace obecní struktury. Tento pozoruhodný proces je připisován především obnově demokratických procesů $\mathrm{v}$ daných zemích, které měly za následek opětné rozdělení rady obcí. Ty byly v předcházejícím období slučovány, aniž by toto slučování zohledňovalo vưli místních obyvatel a lokálních elit (Majerová 2008), (UCLG 2008: 129).

Paradoxně se tak v jiné formě projevuje důsledek radikální defragmentace, která proběhla i v západní Evropě. Zatímco následky tohoto trendu, který má v mnoha prúpadech na svědomí eliminaci místních struktur, specifik, zvyklostí, apod. (palčivě postrádaných především ve státech jižní Evropy) se v západní Evropě řeší, např́klad ve Velké Británii nebo Švédsku, opětným ustanovováním a podporou budování lokálních institucí a zvyklostí, ztracených těmito reformami, v zemích bývalého Východního bloku je toto činěno opětnou fragmentací. Zatímco západní Evropa tak klade důraz spíše na meziobecní spolupráci, jež má napravit předchozí radikální amalgamaci obcí, země bývalého Východního bloku problémy plynoucí z nedemokratické defragmentace řeší možností opětné fragmentace, přičemž tato možnost je obcemi využívána (UCLG 2008: 135).

Zcela jinou kategorii tvoří ty politické systémy, které si procesem defragmentace v uplynulých desetiletích neprošly, což lze vnímat i jako následek zásadní dichotomie v policy týkající se místních samospráv, která se v druhé polovině 20. století projevila vznikem dvou primárních trendů. Britský model vnímal samosprávy jako poskytovatele veřejných služeb a následně tak racionalizoval své působení tak, aby poskytování těchto služeb optimalizoval (např. Švédsko, Dánsko, Finsko, Velká Británie). Francouzský model (např. Itálie, Francie, Španělsko) naopak vnímal samosprávy jako těleso postavené na společenství místních lidí ve smyslu Tönniesova gemeinschaft (Tönnies 1955). To se ve Francii projevuje mimo jiné silně fragmentovanou obecní strukturou, vysokým počtem obcí a jejich nízkou populací (Francie tvoří z hlediska sídelní struktury ojedinělý případ fragmentované obecní struktury, kdy se na jejím území nachází 40 \% všech obcí Evropské unie [CEMR 2008: 5]). Díky tomuto mohou být, a do velké míry také jsou, specifika místních společenství zohledňována. Právě země, jež přijaly francouzský model, ve velké většině nepřijaly racionalizační př́stup $\mathrm{k}$ územnímu uspořádání a neproběhla $\mathrm{v}$ nich zásadnější restrukturalizace místních samospráv či přímo defragmentace obecní struktury.

Od konce 20. století, především od 90. let, je však zjevné, že zejména ekonomické výzvy, jimž musí obce a následně státy čelit, v sobě zahrnují nutnost přijetí územních reforem (Hovgaard, Eythórsson, Fellman 2004). A to takových, které země, jež přejaly britský model, 
provedly již na začátku druhé poloviny 20. století. Př́ípadně obdobných opatření, která by vedla $\mathrm{k}$ důsledkům, jež tyto reformy přinášejí.

Př́lišná fragmentace je obecně vnímána jako negativní prvek, nevhodný pro politickoadministrativní uspořádání země. Proto začaly být prováděny rozsáhlé konsolidační reformy, které měly zastavit narůstající fragmentaci obcí a zvrátit tento všeobecně negativně vnímaný trend opačným směrem. Jednoznačný konsensus ohledně výhodnosti či nevýhodnosti fragmentace obcí však nikdy nebyl přijat. Nebot' ačkoli je defragmentace bezesporu výhodná z ekonomického hlediska, což především v poválečném období hrálo významnou roli, sociologické stanovisko již tak jednoznačné odpovědi nepřináší. Spíše naopak. Hájí hledisko, že existuje silná identifikace obyvatelstva s obcí, což hovoří ve prospěch zachování fragmentované obecní struktury (Klimovský 2009: 183).

Malé municipality a fragmentovaná soustava obcí skýtá řadu kladných i záporných aspektů. Jako pozitivní prvek je nutné vnímat relativní blízkost populace místní vládě, prrímou komunikaci s ní, implicitní kontrolu orgánů veřejné moci, zvýšený potenciál subsidiárních řešení a veškeré další výhody plynoucí z úzkého vztahu mezi představiteli vládní moci a obyvatelstvem. Na druhou stranu může taková blízkost jednotlivých aktérů vést $\mathrm{k}$ tvorbě degenerativních prvků, jakými jsou klientelismus, nepotismus a korupce. Př́liš těsné splývání těchto dvou rovin může být někdy natolik úzké, že neumožňuje (nebo pouze velice obtížně) odpoutání se od osobních vazeb a zájmů. Nevýhodou jsou také omezené prostředky na poskytování služeb ve srovnání s těmi poskytovanými většími municipalitami. V malých municipalitách se také může ukázat obtížným vykonávat konkrétní funkce svěrené centrální vládou, byt’ takové problémy jsou obvykle řešeny meziobecní spoluprací či vytvářením svazků obcí (Local Governments 2012). I proto je fragmentace vnímaná jako problém hodný řešení (Klimovský 2009: 183), což akceptovala většina evropských zemí. V současnosti se tedy $\mathrm{v}$ této otázce prosazují konsolidační tendence (Klimovský 2009: 188).

Jednou z hlavních výzev v tomto ohledu je i narůstající trend urbanizace. Polovina světového obyvatelstva nyní žije ve městech a odhad pro následující tři desetiletí stanovuje, že urbanizace a objem osob žijících ve městech bude i nadále narůstat. Jedná se o radikální změnu dosavadního trendu, nebot' v poslední třetině 20 . století byl poměr nárůstu obyvatelstva mezi venkovskými a městskými oblastmi mnohem vyrovnanější. Následný pokles obecní fragmentace tak povede jak k jejím pozitivním, tak k jejím negativním trendům (Cohen 2006).

\section{Diverzita defragmentace evropských municipalit}

Proces defragmentace má za primární cíl minimalizaci ekonomické nevýhodnosti plynoucí ze skutečnosti, že obce musí poskytovat určité spektrum služeb, o náklady na jejichž plnění by se při jejich defragmentaci mohly dělit větší celky (Provazníková 2009: 15, Jóhannesson 2007: 163, Hovgaard, Eythórsson, Fellman 2004: 33nn). Přijetím zákona z roku 1999 byl ve Francii trend spolupráce obcí, který by minimalizoval tuto ekonomickou nevýhodnost, dále prohlouben finanční podporou, která znamenala rozvoj meziobecní spolupráce a vznik meziobecních veřejných korporací s daňovými pravomocemi, jež přesahují pravomoci jednotlivých obcí. Začátkem roku 2007 tak bylo více než 33000 francouzských obcí, zahrnujících takřka 55 miliónů obyvatel, sdruženo v2 588 meqiobcí. Podobné trendy ustanovování neobecních struktur meziobecní spolupráce proběhly také v Mad’arsku, Itálii a Španělsku (UCLG 2008: 136).

Výše zmíněný trend je nicméně záležitostí posledních patnácti let, zatímco zásadní defragmentační procesy probíhají na evropském kontinentu již od 50. let, kdy Rakousko 
zredukovalo počet svých obcí na polovinu a Švédsko dokonce na osminu. Tento trend následně převzalo Dánsko, které na začátku 70. let začalo počet svých obcí snižovat na pětinu (v roce 2007 prošlo další reformou, jíž byl počet obcí snížen z 271 na 98 [CEMR 2008: 9]), dále západní Německo v 60. a 70. letech na třetinu, Belgie v roce 1975 na čtvrtinu, Holandsko (kde proces defragmentace zabral celou polovinu 20. stoletî) na polovinu a Finsko, které si prošlo neúspěšnou obecní reformou na přelomu 60. a 70. let a v roce 2009 se mu podařilo snížit počet obcí o 67 (CEMR 2008: 5). Úspěšně totiž zavedlo nový model slučující dvě, tři i více obcí do jedné (např́klad obec Salo tak vznikla sloučením desítky obcí a Hämeenlinna sloučením šesti obcí (CEMR 2008: 20). Později začali s procesem defragmentace v Litvě (1994), kde snížili počet obcí na desetinu, a v Řecku (1997), kde jej snížili na šestinu. Od roku 1998 se o defragmentaci pokouší Lotyšsko, jehož proklamovaným cílem je snížení počtu obcí na pětinu.

Obdobný trend defragmentace proběhl v druhé polovině 20. století také v zemích Východního bloku, ovšem zcela jiným způsobem se zcela jinou motivací a se zcela jinými dlouhodobými následky než v demokratických zemích. Tyto defragmentace ve své obecnosti proběhly proti vůli lokálních obyvatel, bez respektování místních specifik, a jejich cílem byla centralizace obecních struktur a vykonávaných funkcí, vyplývající z ideologie daných režimů a snahy o kontrolu společnosti. Tato defragmentace se následně projevila po přechodech těchto režimů k demokracii, kdy byl nastolen reverzní trend opětné fragmentace. Obnovení historických obcí v jejich historickém rámci a rozsahu bylo vnímáno jako demokratický trend znovuzavádějící právo lidu na určení své vůle. V ČR tak bylo od roku 1989 obnoveno více jak dva tisíce obcí, např́klad ve Slovinsku se počet obcí zvýšil v roce 2006 už na 210, zatímco v roce 1976 jich bylo pouhých 54 (CEMR 2008: 5-6). Př́źnačný př́klad vývoje postkomunistických zemí v oblasti municipální struktury poskytuje i Mad’arsko, v němž od 70. let docházelo k nucenému slučování obcí, kdy bylo dosaženo snížení počtu obcí z 3021 na 1 364. Reformní zákony v letech 1990 a 1994 však přiznaly každé obci ústavní právo na samosprávu, což vedlo k opětné fragmentaci a nárůstu počtu obcí na více než tři tisíce (3 071 v roce 1990, 3131 v roce 1999) (Fekete 2002, Pfeil 2010).

\section{Analýza trendů evropské defragmentace a jejich explikace}

Rozdílnost př́stupu evropských zemí k defragmentacím municipálních struktur, následky rozdělení Evropy do bipolárních bloků, které se vyvíjely odlišným způsobem, odlišné trendy vývoje po překonání bipolárního rozdělení, geografická, kulturní a sociální rozdílnost a řada dalších aspektů činí snahu o zobecnění defragmentačních trendů komplexní a nesnadnou záležitostí. Na jednu z možných typologií poukazuje Sharp, který dělí evropské státy na severní, kde se počet obcí průměrně snížil o $41 \%$, a na jižní, kde proběhly malé reformy a počet obcí se průměrně snížil o $5 \%$. Tato typologie je však problematická už z toho důvodu, že např́klad v Itálii a Portugalsku se naopak počet obcí zvýšil (Bogason 1996). Severo-jižní dělení defragmentace je př́liš zjednodušující a neobsahuje proměnnou postkomunismu a následků tohoto aspektu pro municipální strukturu dotčených států. V zájmu komplexnějšího, byt' nutně zobecňujícího zkoumání základních trendů defragmentace na evropském kontinentě byla proto pro účely této práce provedena analýza za použití metody QCA (Qualitative Comparative Analysis), jejímž cílem bylo zahrnutí postkomunistické proměnné do typologie vývoje defragmentace. Za primární kritérium této typologie bylo zvoleno období, v němž defragmentační procesy probíhaly (jak však vyplývá z tabulky kódovaných dat, viz Tab. 1, zahrnuty jsou i země, v nichž defragmentace neproběhla), nikoli konkrétní model defragmentace. 
Užitá metoda umožňuje prostř̌ednictvím kvalitativní analýzy rozeznat společné prvky sledovaných jevi̊, a rozlišit tak průvodní prvky sledovaných př́padů. Jejím cílem tedy bylo na základě vytipovaných zkoumaných prvků rozdělit země na základě časového kritéria průběhu defragmentace obecních struktur a tak vytvořit typologii defragmentujících zemí, s kterou by se dalo dále pracovat při zkoumání zemí, u nichž lze defragmentaci očekávat.

Zkoumanými podmínkami použitými pro tuto analýzu byly zvoleny defragmentace před rokem 1989 (dante89), defragmentace po roce 1989 (dpost89), př́slušnost země k postkomunistické skupině zemí (postcom) a reverzní trend (de)fragmentace po přechodu $\mathrm{k}$ demokracii (reverzpostcom). Jak je z tabulky kódovaných dat patrné, po prvotní analýze byla analýza doplněna o další podmínku - příslušnost k pobaltským zemím. Tato podmínka byla doplněna jako následek počáteční nekonzistence výsledků a jejím následkem byla hypotéza, že postkomunistické země procházejí opětnou fragmentací, rozšířena o zjištění, že do této množiny nespadají pobaltské země, které naopak opětnou fragmentací po přechodu $\mathrm{k}$ demokracii neprošly a přijaly defragmentační proces typický pro země nespadající do množiny postkomunistické. Analýza tak poskytla zajímavý sekundární závěr ohledně této množiny zemí (Tab. 1).

Výzkumný vzorek zemí vybraných $\mathrm{k}$ analýze byl zvolen na základě dostupných dat a reprezentativnosti zemí, v zájmu validity závěrů a pokrytí všech trendů a možností, které zkoumaná otázka předpokládá. Byly do něj zahrnuty země postkomunistické i země, jež neprošly komunistickým režimem, země, jež přijaly britský i francouzský model municipální struktury, země geograficky spadající do severní, jižní, západní, východní i střední Evropy a země, jež defragmentací prošly v několika vývojových fázích, najednou, či u nich defragmentace vůbec neproběhla. Zároveň byly zahrnuty země, jež prošly reverzním procesem po přechodu k demokracii, i ty, které tímto procesem neprošly, a naopak trend přijatý za komunistického režimu dále prohloubily.

Tab. 1

\begin{tabular}{|l|l|l|l|l|l|}
\hline \multicolumn{7}{|c|}{ Tabulka kódovaných dat } \\
\hline caseid & dante89 & dpost89 & Postcom & Reverzpostcom & baltic \\
\hline AUS & 1 & 0 & 0 & 0 & 0 \\
\hline BEL & 1 & 0 & 0 & 0 & 0 \\
\hline CS & 1 & 0 & 1 & 1 & 0 \\
\hline DAN & 1 & 0 & 0 & 0 & 0 \\
\hline EST & 1 & 1 & 1 & 0 & 1 \\
\hline FIN & 1 & 0 & 0 & 0 & 0 \\
\hline FRA & 0 & 0 & 0 & 0 & 0 \\
\hline GER & 0 & 1 & 0 & 0 & 0 \\
\hline GRE & 1 & 1 & 0 & 0 & 0 \\
\hline HOL & 1 & 1 & 0 & 0 & 0 \\
\hline HUN & 1 & 0 & 1 & 1 & 0 \\
\hline ICE & 0 & 1 & 0 & 0 & 0 \\
\hline
\end{tabular}


Tomáš Váňa: Procesy evropské defragmentace jako inspirativní nástroj policymaking

\begin{tabular}{|l|l|l|l|l|l|}
\hline ITA & 0 & 0 & 0 & 0 & 0 \\
\hline LAT & 1 & 1 & 1 & 0 & 1 \\
\hline LIT & 1 & 1 & 1 & 0 & 1 \\
\hline NOR & 1 & 0 & 0 & 0 & 0 \\
\hline POL & 1 & 0 & 1 & 1 & 0 \\
\hline SLO & 1 & 0 & 1 & 1 & 0 \\
\hline SPA & 0 & 0 & 0 & 0 & 0 \\
\hline SWE & 1 & 0 & 0 & 0 & 0 \\
\hline SWI & 0 & 0 & 0 & 0 & 0 \\
\hline UK & 1 & 0 & 0 & 0 & 0 \\
\hline YUG & 1 & 0 & 1 & 1 & 0 \\
\hline
\end{tabular}

\section{Zdroj: Autor}

Vysvětlivky:

baltic: baltická země

dante89: defragmentace před rokem 1989

dpost89: defragmentace po roce 1989

postcom: př́slušnost země k postkomunistické skupině zemí

reverzpostcom: reverzní trend (de)fragmentace po přechodu k demokracii

Z kódovaných dat byla prostřednictvím crisp set analysis vytvořena pravdivostní tabulka, která analyzované prrípady rozdělila do šesti množin, které pokryly $100 \%$ zkoumaných př́padů v plné konzistenci. Ze šesti množin byly dvě množiny kódovány jako prrípady zemí náležejících do nadmnožiny postkomunistických zemí (Tab. 2).

Tab. 2

\begin{tabular}{|l|l|l|l|l|l|l|l|l|l|}
\hline \multicolumn{8}{|c|}{ Pravdivostní tabulka } \\
\hline reverzpostcom & baltic & dpost89 & dante89 & number & postcom & raw cons. & PRI cons. & SYM cons. \\
\hline 0 & 0 & 0 & 1 & 7 & 0 & 0.000000 & 0.000000 & \\
\hline 1 & 0 & 0 & 1 & 5 & 1 & 1.000000 & 1.000000 & 1.000000 \\
\hline 0 & 0 & 0 & 0 & 4 & 0 & 0.000000 & 0.000000 & \\
\hline 0 & 1 & 1 & 1 & 3 & 1 & 1.000000 & 1.000000 & 1.000000 \\
\hline 0 & 0 & 1 & 0 & 2 & 0 & 0.000000 & 0.000000 & \\
\hline 0 & 0 & 1 & 1 & 2 & 0 & 0.000000 & 0.000000 & \\
\hline
\end{tabular}

Zdroj: Autor 


\section{Schéma 1}

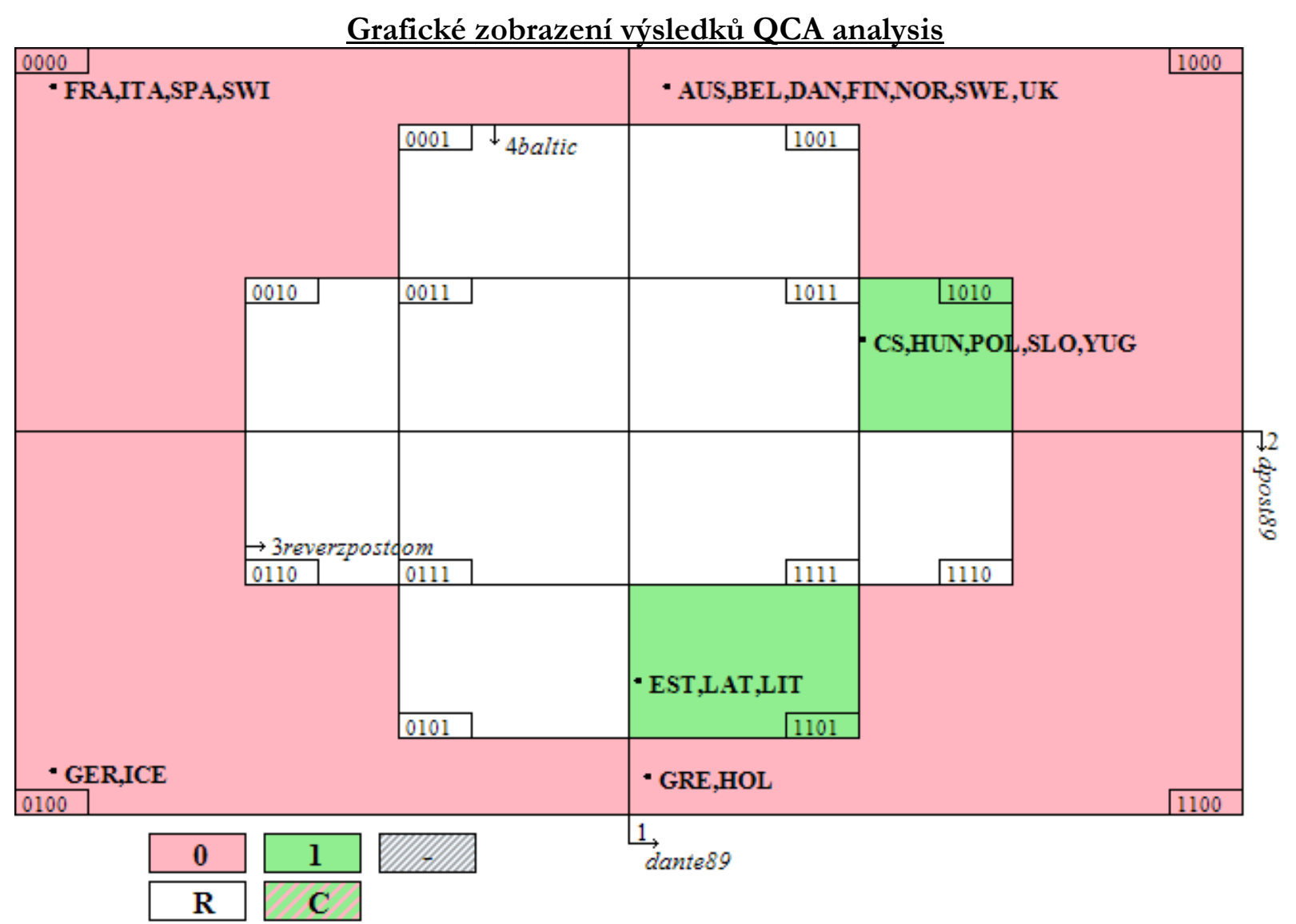

Zdroj: Autor

Jak z pravdivostní tabulky (Tab. 2) a z grafického zobrazení (Schéma 1) vyplývá, existuje zřejmá souvislost mezi př́slušností k postkomunistickým zemím a způsobem defragmentace. Mezi postkomunistickými zeměmi a defragmentačními tendencemi existuji dvě dominantní tendence, které analýza ukázala jako vázané geografickými aspekty. Jednu skupinu tvoř́ postkomunistické země, které prošly vobdobí komunismu procesem defragmentace a po přechodu k demokracii prošly opačným procesem opětné fragmentace. Mezi tyto země patř́ Československo a jeho nástupnické státy Česká republika a Slovensko, dále Mad’arsko, Polsko, Jugoslávie a Slovinsko. Druhou skupinu tvoří postkomunistické země, které prošly v období komunismu procesem defragmentace a po přechodu $\mathrm{k}$ demokracii prošly opětným nebo pokračujícím procesem defragmentace a nedošlo u nich tedy k reverzní akci. Tyto země odlišuje jediná charakteristika, a sice geografické umístění (a další aspekty s tímto související), nebot' se jedná o pobaltské státy Litvu, Lotyšsko a Estonsko.

Výsledky analýzy při zvolení středního řešení (intermediate solution), které bylo vyhodnoceno jako optimální, ukazují, při nestanovení předpokladů (assumptions), dvojici řešení, která potvrzují předchozí řešení (Tab. 3). 
Tomáš Váňa: Procesy evropské defragmentace jako inspirativní nástroj policymaking

Tab. 3

\begin{tabular}{|l|c|c|c|}
\hline \multicolumn{4}{|c|}{ Analýza pravdivostní tabulky: Střední řešení } \\
\hline & Hrubé pokrytí & Jedinečné pokrytí & Konzistence \\
\hline dante89* dpost89* $\sim$ baltic* reverzpostcom & 0,625000 & 0,625000 & 1,000000 \\
\hline dante89*dpost89*baltic* $\sim$ reverzpostcom & 0,375000 & 0,375000 & 1,000000 \\
\hline Pokrytí výsledku: 1,000000 & & & \\
\hline Konzistence výsledku: 1,000000 & & & \\
\hline
\end{tabular}

Zdroj: Autor

Mezi země náležející do termu dante89* dpost89* baltic*reverzpostcom patř́: CS $(1,1)$, HUN (1,1), POL (1,1), SLO (1,1), YUG (1,1). Mezi země náležející do termu: dante89*dpost89*baltic* reverzpostcom patř́ EST $(1,1), \operatorname{LAT}(1,1), \operatorname{LIT}(1,1)$.

\section{Typologie evropské municipální defragmentace a prediktivní implikace pro př́pad České republiky}

Z výsledků analýzy vyplývá jeden zásadní faktor, kterému se bude následující část textu věnovat. Nejpočetněji je ve zkoumaném vzorku zastoupena skupina zemí, u níž defragmentace proběhla v prvotním období, a jak bylo v dosavadním textu ukázáno, aktuálně se s negativními následky této defragmentace vypořádává, např́klad prostřednictvím znovu ustanovování tradičních a zaniklých struktur a institucí nebo jejich substituty. Druhá nejpočetnější skupina zemí je skupina postkomunistických zemí, mezi něž patří i Česká republika, u nichž došlo k reverzním trendům. Obě tyto skupiny prošly ve sledovaném období z hlediska procesu defragmentace $\mathrm{v}$ zásadě obdobným procesem, lišily se pouze prríslušností k bipolárním blokům. Další skupinou je skupina zemí, u nichž defragmentace neproběhla, dále skupina pobaltských států a rovněž skupina zemí, u nichž defragmentace proběhla jak v druhé polovině 20. století, tak i v relativně aktuální době. Konečně poslední skupinu zemí tvoři dvojice, $\mathrm{u}$ nichž defragmentace proběhla $\mathrm{v}$ poměrně nedávné době, a právě tato skupina zemí proto poskytuje relevantní údaje umožňující pozorování, jak optimalizovat proces defragmentace, v dřívější části textu označený z ekonomického hlediska za nezbytný. Tato dvojice, konkrétně Island a Německo, těžily svou pozdní defragmentací ze zkušeností zemí, u nichž defragmentace proběhla dříve, a mohly se tak poučit z negativních aspektů těchto defragmentací.

Máme-li zjednodušeně a v obecnosti shrnout dosavadní poznatky, můžeme konstatovat, že u zemí s britským modelem proběhla prŕliš radikální defragmentace, která je dnes řešena institucionální obnovou. V zemích s francouzským modelem defragmentace neproběhla, ale byla posílena meziobecní spolupráce. V postkomunistických zemích proběhla fragmentace jako následek předchozí nedemokratické a umělé defragmentace. Pobaltí je v této množině separátní skupinou, nebot' je postkomunistické, ale zároveň defragmentovalo.

Pro Českou republiku z přednesených poznatků vyplývá, že lze očekávat, že i na jejím území v důsledku ekonomické nezbytnosti proběhne municipální defragmentace. Vzhledem k tomu, že tento proces bude probíhat při existenci zkušeností $\mathrm{z}$ defragmentačních procesů $\mathrm{v}$ jiných zemích, bude tak mít možnost vyvarovat se chyb prvotně defragmentujících zemí, které následně musely přijmout částečně reverzní proces, a od zemí (Francie), které zavedly meziobecní spolupráci. Především se však bude moci inspirovat př́klady zemí, které začaly defragmentovat až v nedávné 
době, byly v tomto procesu úspěšné a inspirovaly se zkušenostmi okolních politických systémů (Island, Německo).

Z hlediska typologie defragmentace proto patří př́pad islandské defragmentace mezi ojedinělé a z komparativního hlediska podnětné, a to nejen pro Českou republiku, ale pro všechny státy spadající do kategorie postkomunistických států, jež opětně fragmentovaly svou municipální strukturu, nebo neprošly procesem defragmentace. Podobně jako v Holandsku docházelo na Islandu k markantnímu slučování a snižování počtu obcí, tento proces však nabyl své nejvyšší intenzity ve srovnání s jinými defragmentujícími zeměmi značně opožděně: až v 90. letech 20. století. Navíc se jedná o prŕklad země, kde fragmentace dosáhla neobvyklého rozsahu za poslední půlstoletí se počet obcí na tomto ostrovním státě snížil o více než polovinu (Local Governments 2012), což v souvislosti s nízkým počtem obyvatelstva a souvisejícím nízkým počtem obcí skýtá unikátní př́ležitost pro vytvoření prrípadové studie. V následném textu se proto budu věnovat konsolidačním procesům, které na Islandu probíhaly v druhé polovině 20 . století, a budu demonstrovat některé zásadní a zobecnitelné trendy defragmentace. Prostřednictvím př́padové studie ilustrující jeden z procesů defragmentace tak bude provedena deskripce průběhu islandské defragmentace, kdy hlavními operačními nástroji bude obsahová analýza primárních legislativních a exekutivních dokumentů, doplněných sekundárními zdroji a prameny. $^{2}$

Ilustrativní studie Islandu byla vybrána, a samotný Island jako vzorový př́ílad optimální defragmentace obecní struktury, ze dvou hlavních důvodů. Především lze islandskou defragmentaci označit za úspěšnou, a to $\mathrm{z}$ toho důvodu, že proběhla $\mathrm{v}$ konsensu s obyvatelstvem (Hovgaard, Eythórsson, Fellman 2004: 23). To je rozdíl proti komunistickému Československu a dalším zemím Východního bloku, kde sice proběhla před rokem 1989 defragmentace, ale na nelegitimních základech. Islandská defragmentace proběhla na základě místních referend, dobrovolně, měla pozitivní motivační dopad na navazování meziobecní spolupráce a přinesla finanční úspory díky diverzifikaci finančních nákladů na výkon veřejné správy. Z tohoto by se Česká republika mohla při své př́padné defragmentaci poučit. Druhý důvod volby Islandu byl, že se společně s Německem, jak ukázala analýza QCA, jednalo o stát, kde defragmentace z časového hlediska proběhla později než v ostatních evropských státech, což umožnilo Islandu těžit ze zkušeností zemí, v nichž defragmentace proběhla dřive. Byt’ lze vznést oprávněnou námitku, že Česká republika si s Islandem není podobná v počtu obcí či v průměrném počtu jejich obyvatel, pro tuto práci byla za základní komparativní hledisko zvolena úspěšnost defragmentace a její časový rozměr, umožňující těžení ze zkušeností a př́ikladu dobré praxe, které z tohoto časového prvku vyplývají.

\section{Islandské osídlení}

Island je z hlediska zkoumání fragmentace obcí zemí značně specifickou. Rozkládá se na 103000 $\mathrm{km}^{2}$, přičemž převážná část obyvatelstva žije na pobřeží, z toho 62 procent v regionu hlavního města Reykjavík. Pouze zhruba 25 municipalit má populaci přesahující 1000 obyvatel, z nichž největší, mimo Reykjavík, je Akureyri s 15000 obyvateli (Jonsson 2002:22). S 313000 obyvateli patři s 2,9 obyvateli na $\mathrm{km}^{2}$ mezi nejǔidčeji obydlené státy Evropy (Iceland 2010). Z hlediska zkoumání fragmentace obcí a následného procesu jejich defragmentace tak díky jejich ř́dkosti

\footnotetext{
${ }^{2}$ Je však v tomto kontextu nezbytné upozornit, že existuje pouze omezené spektrum dostupných pramenů
} zabývajících se předmětnou problematikou. 
poskytuje unikátní objekt výzkumu. Především od 90. let 20. století na Islandu probíhají procesy, které lze považovat z hlediska komunální politiky za zajímavé. Následkem policy centrální vlády v posledních desetiletích klesal počet jeho obcí, zatímco jejich rozloha a míra urbanizace stoupala. I na prríkladu malé země tak lze zkoumat procesy, které nejsou zdaleka ojedinělé a navíc stále procházejí dynamickým vývojem.

Počátky prvního osídlení Islandu jsou kladeny do roku 874 (Vilhjalmsson 2005), kdy se prvními obyvateli tohoto druhého největšího evropského ostrova (Iceland 2010) stali Norové a Kelti. V roce 930 bylo v oblasti vytvořeno první centrální soudní a legislativní shromáždění Althing a pro celou zemi byl ustaven jednotný zákoník (Reynarsson 1999). Písemná historie zaznamenávající vytvoření místní správy se začíná tvořit zhruba od začátku desátého století, tedy krátce po osídlení Islandu (Jonsson 2002: 3). V tomto kontextu je cenným zdrojem relevantních dat a informací stará kniha zákonů Grágás, pocházející z 12. století (Jüptner, Polinec, Švec 2007: 56), která obsahuje několik zmínek o místní správě, její struktuře, síle a odpovědnosti.

V roce 1262 vytvořil Island unii s Norským královstvím. Poté, co se tato severská monarchie dostala v roce 1380 pod nadvládu Dánska, se Island stal dánským dominiem (Jonsson 2002: 3). Už při spojení s norskou monarchií začala být potlačována nezávislost islandských obcí (Jüptner, Polinec, Švec 2007: 56), a to natolik, že začátkem 19. století již prakticky nelze o její existenci hovořit. Až královský výnos Local Government Act ze dne 4. května 1872 znovu ustavil místní správu. Ta byla vytvořena na bázi starověkých komun, na rozdíl od Anglie či Skandinávie, kde místní správa kopírovala farní uspořádání. Tato omezená samospráva byla v roce 1904 dále rozšířena (Jonsson 2002: 3) a o rok později byl přijat první zákon o místní samosprávě (Jüptner, Polinec, Švec 2007: 56).

S koncem první světové války se v roce 1918 stal Island samostatným státem, a to v královském spojení s Dánskem. Definitivní samostatnost získal v roce 1944, kdy svou unii s Dánskem zrušil a stal se suverénní republikou (Jonsson 2002: 3).

\section{a. Defragmentace}

Do 90. let 20. století (Kersting 2003: 36) municipální uspořádání víceméně odpovídalo direktivě dánského krále Kristiána IX. z roku 1872. Země byla rozdělena do 172 municipalit. Na začátku 20. století se ale počet municipalit začal zvyšovat, nebot' se $\mathrm{v}$ mnoha částech země začaly urbanistické oblasti osamostatňovat. Počet municipalit dosáhl své maximální míry v roce 1950, kdy jich Island evidoval 229 (Local Governments 2012). Tento trend zvyšování počtu municipalit ale $\mathrm{v}$ polovině 20 . století nabral opačný směr. ${ }^{3}$

V roce 1990 byla za vzájemné spolupráce ministerstva sociálních věcí a Asociací místních samospráv ${ }^{4}$ spuštěna kampaň za slučování municipalit (Local Governments 2012). V té době měl Island 204 municipalit, z nichž 30 mělo status města a zbylých 174 bylo okresy. V roce 1994 byl

\footnotetext{
${ }^{3}$ Zkoumání početního vývoje municipalit poněkud komplikuje problematika municipality Sléttuhreppur, jež byla v roce 1953 opuštěna a od té doby nebyla do sídelní struktury započítávána (formálně byla sloučena s Ísafjarðarkaupstaðar zákonem z roku 1995). Pro zachování přehlednosti se jí zde ale nebudeme zabývat (The Association of Local Authorities in Iceland 2012).

${ }^{4} \mathrm{~V}$ islandské komunální politice plní Asociace místních samospráv významnou a nezastupitelnou roli. Je základní platformou pro spolupráci mezi místními správami, reprezentuje je a hájí jejich zájmy při vyjednávání s vládou a politickými stranami na Islandu i v zahraničí. Místním autoritám poskytuje informace, poradenské služby a stará se o běžné úkoly, například kolektivní vyjednávání s uniemi municipálních zaměstnanců. Byla založena roku 1945 dvaapadesáti místními správami, ovšem už v roce 1973 byly její součástí všechny místní správy v zemi (Jonsson 2002: $5)$.
} 
již počet municipalit 171, což znamenalo úbytek o 33 municipalit ve srovnání s předchozím obdobím. Klesající trend probíhal i nadále, takže v roce 1998 byl celkový počet municipalit 124 a o čtyři roky později 105 (The Association of Local Authorities in Iceland 2012).

Ministerstvo sociálních věcí a Asociace místních samospráv pro úspěch kampaně spustily obdobnou akci opět v roce 2005. Obyvatelům každé municipality tak bylo umožněno ve volbách vyjádřit, zdali si přejí sloučení své municipality s jinou. O tom, nakolik byla tato kampaň úspěšná, svědči skutečnost, že $\mathrm{v}$ roce 2006 bylo na Islandu pouze 79 municipalit (Tab. 4) (Local Governments 2012).

Tab. 4

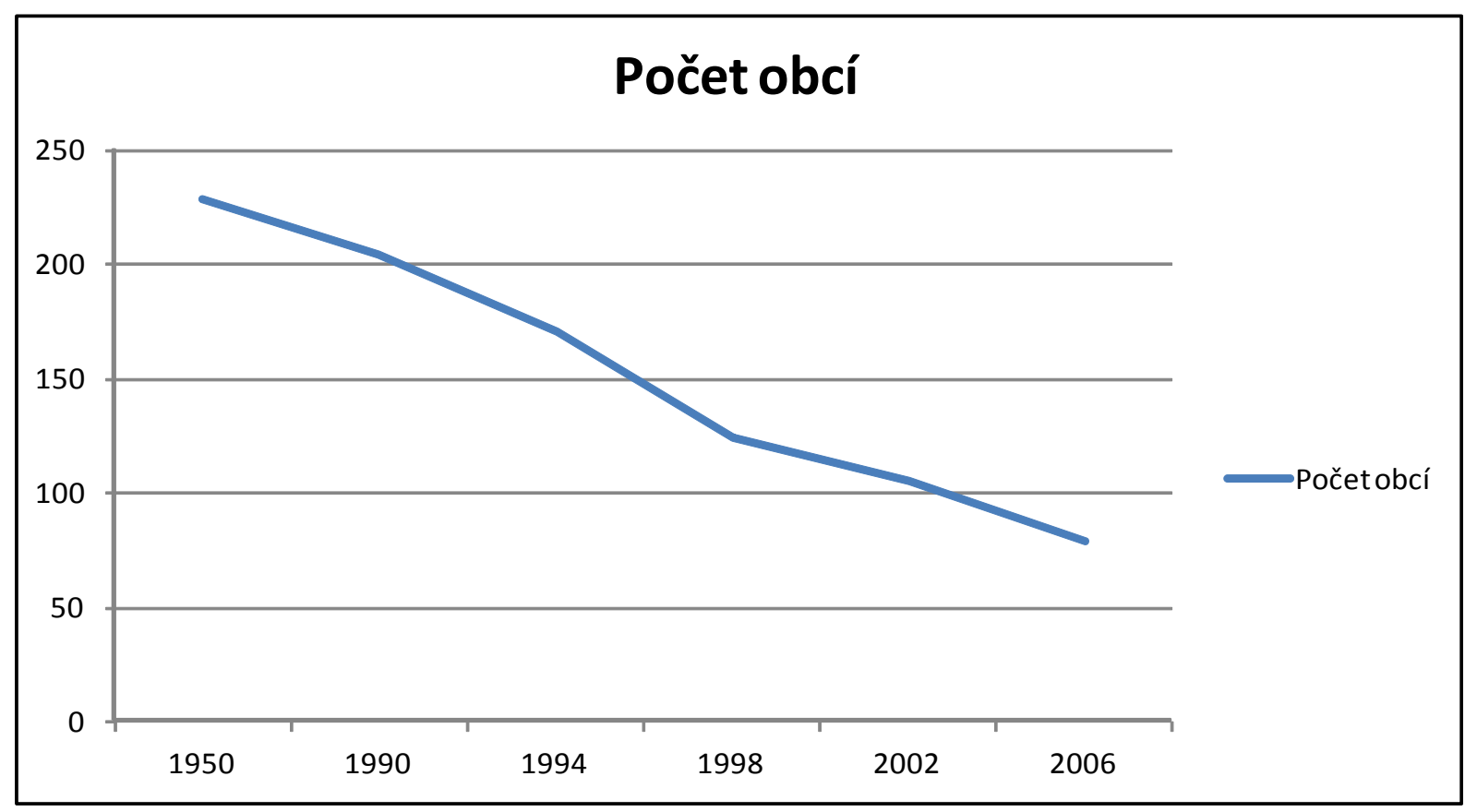

Zdroj: Autor

Tyto kampaně, které měly rozsáhlé důsledky v oblasti místního vládnutí, byly důsledkem změn, které se v posledních desetiletích odehrávaly nejen na evropském kontinentě. Zatímco před stovkami let byly hranice místních autorit kresleny kolem farmářských okresů, ty se v moderní době ukázaly být nevyhovujícími zejména z toho důvodu, že byly př́liš malé na to, aby mohly sloužit jako místní služební jednotky. Další převratné změny byly zaznamenány v oblasti dopravy a komunikace. Proběhla rovněž velká migrace obyvatelstva z venkova do měst. Trend urbanizace vedl ke změnám $\mathrm{v}$ hospodářství, nebot' $\mathrm{v}$ jeho důsledku ztratila značnou část svého významu oblast zemědělství ve prospěch zejména rybolovu, zpracovatelského průmyslu a služeb. Ty se staly dominantními ekonomickými aktivitami (Jonsson 2002: 8).

\section{b. Přenos pravomocí}

$\mathrm{Na}$ Islandu jsou dvě úrovně samosprávy: centrální a místní municipality (Jóhannesson 2007). Paralelně s procesem defragmentace proběhla i reforma místních vlád, respektive transfer služeb a funkcí mezi oběma vládními úrovněmi, tedy centrální a lokální. Zároveň proběhla také reforma financování místních vlád, municipálních vztahů mezi centrem a periferií, dále se odehrály změny v administrativních procedurách a v dalších dílčích oblastech. Hlavním cílem těchto kroků bylo 
vytvoření místních struktur schopných efektivně naplňovat nejrůznější lokální služby, vytvářet lokální demokracii a posilovat místní samosprávu (Jonsson 2002: 8).

Dnes jsou municipality zodpovědné za široké spektrum oblastí (Bogason 1996: 8), především za požární ochranu, registraci voličů, předškolní vzdělávání, školky a jesle, rodinnou sociální péči, domovní sociální péči, ubytování, územní plánování, regionální a prostorové plánování, vodu a kanalizaci, sběr a odpad, hřbitovy a krematoria, jatka, ochranu př́rody, muzea a knihovny, parky a otevřená prostranství, sport a volný čas, dopravu a př́istavy (Rada Evropy 2005: 17-19).

Snad nejzásadnější kompetenční oblast místních samospráv, a sice zodpovědnost za udržování základního a nižšího středního školství, byla na místní správu převedena v roce 1996. $\mathrm{V}$ závislosti na tomto kroku byla odpovídajícím způsobem navýšena místní daň z př́imu (Jonsson 2002: 8).

\section{c. Legislativa}

Držitelem suverénní moci je na Islandu parlament, jenž zde nese jméno Althing. Místní správa od něj a jím tvořené legislativy odvozuje svou moc. Islandská ústava nepřipouští změnu v autonomii místní správy bez dodatku k Ústavě. Ovšem také předjímá, že výkon místní správy podléhá zákonným omezením a je prováděn pod dohledem centrální vlády (Jóhannesson 2007). Parlament je tak oprávněn provést jakékoli změny $\mathrm{v}$ pravomocech municipalit, a to zejména takové, které považuje za nezbytné $\mathrm{v}$ rámci plnění islandských mezinárodních závazků. Autonomie místní správy je potvrzena Evropskou chartou místní samosprávy, jež byla vytvořena pod patronací Rady Evropy a podepsaná Islandem 20. listopadu 1985 (Structure and operation 2005: 5).

Místní správa má na základě článku 78 Ústavy pravomoc rozhodovat o svých záležitostech podle ustanovení zákona (Jonsson 2002: 5). Rozsah těchto záležitostí sahá až po míru, do jaké nejsou upraveny jinými nařízení (Structure and operation 2005: 15). Ovšem ačkoli jsou zákony vytvářeny $\mathrm{v}$ Althingu a mnohé policies jsou určovány centrální vládou, místní správy mají svobodu je prrizpůsobovat svým lokálním podmínkám. Hlavní legislativní rámec pro místní vlády je vymezen dokumentem Local Government Act č. 45 z roku 1998 (Jonsson 2002: 5; Iceland 1998).

Podle článku 68 Local Government Act je centrální vláda prostřednictvím odpovídajícího ministerstva povinna usilovat o zvětšování municipalit prostřednictvím spojování municipalit s malým počtem obyvatel ve větší a efektivnějš́i jednotky. Toto má vykonávat ve spolupráci s jednotlivými municipalitami, Asociací místních samospráv a regionálními federacemi municipalit.

Slučování obcí je však možné pouze zákonem podle článku 3 Local Government Act. Tato pravomoc rovněž náleží ministerstvu zodpovědnému za místní správu. Samotné municipality mají rovněž pravomoc vyvolat proces sloučení a od 90. let 20. století tohoto práva také ve značné míre využívají (Structure and operation 2005: 6).

Mají-li dvě či více municipality intenci se sloučit, zvolí si komisi, jež prozkoumá možnost jejich sloučení. Jakmile komise vydá své stanovisko ohledně možnosti sloučení, místní správy zařadí tuto otázku na svou agendu. Téma je dvakrát prodiskutováno bez hlasování. Po debatách místních autorit je vypsáno místní referendum o sloučení. Povinnost vypsat referendum v prrípadě návrhu na sloučení stanoví článek 90 Local Government Act. Čas referenda, který musí být stejný pro všechny zúčastněné obce, je určen místními autoritami. Článek 91 Local Government Act stanoví, že municipality mohou být spojeny pouze tehdy, souhlasí-li s tímto 
záměrem prostá nadpoloviční většina voličů v každé obci. Dojde-li ke schválení sloučení, místní správy se dohodnou na finančních otázkách vyplývajících ze sloučení municipality, počtu reprezentantů potřebných pro vytvoření nové místní správy či jménu municipality a na dalších odpovídajících otázkách. Rozhodnutí je následně odesláno na ministerstvo, které o sloučení rozhoduje.

Jakmile sloučení obcí proběhne, může být zpětně zvráceno již pouze legislativní cestou (Structure and operation 2005: 7).

\section{d. Existence a funkce obce}

Článek 6, sekce 1 Local Government Act stanoví, že minimální počet obyvatel obce je padesát. Sekce 2 stanoví, že pokud počet obyvatel klesne pod padesát ve třech po sobě jdoucích letech, ministerstvo musí podniknout kroky vedoucí ke sloučení takové obce se sousední municipalitou. Za takových podmínek může být také menší municipalita rozdělena mezi několik sousedících municipalit. Podle sekce 3 jsou připuštěny výjimky, pokud by takový krok dle názoru ministerstva bránil obyvatelům malé municipality v navázání soudržného vztahu sobyvateli sousední municipality.

Všechny municipality mají podobnou základní strukturu a povinnosti vyplývající ze zákona (Bogason 1996: 174). Reálný záběr těchto povinností a nutnost konkrétních struktur však záleží na velikosti a počtu obyvatel každé municipality. Malé municipality jsou často nuceny spolupracovat nebo uzavírat smlouvy o poskytování služeb se sousedními municipalitami, aby mohly svým obyvatelům poskytovat určité služby (Structure and operation 2005: 7).

Je zjevné, že mnohé municipality jsou př́liš malé, aby mohly plnit své povinnosti. Základní funkce jsou dvojí: demokratická a administrativní. První umožňuje členům místní komunity podílet se na místních záležitostech a druhá umožňuje aplikovat na prosazované policies místní specifika (Jonsson 2002: 5).

Vědom si tohoto problému fragmentace obcí a z ní vyplývající neschopnosti obcí plnit některé své povinnosti, jmenoval ministr sociálních věcí v srpnu 2003 operační skupinu. Ta dostala za úkol koordinovat společnou iniciativu vlády a Asociace místních samospráv ve směru posílení místní vlády. Byla jmenována podkomise, která měla předkládat návrhy na způsoby zmenšení počtu obcí. V březnu 2005 tato podkomise prezentovala své závěry, v nichž uvedla, že do roku 2006 by počet místních autorit mohl být snížen na 46. Na základě tohoto odhadu bylo 8 . ř́jna 2005 v každé s tímto návrhem související obci uspořádáno referendum o této otázce. Většina obyvatel ve většině obcí však s návrhy podkomise nesouhlasila. Ve 41 municipalitách hlasovali obyvatelé proti sloučení. Ve 20 naopak se sloučením souhlasili. Pouze jeden návrh byl přijat většinou voličů ve všech zainteresovaných municipalitách.

V listopadu 2004 a dubnu 2005 byly další tři návrhy na amalgamaci schváleny v referendu (Structure and operation 2005: 33).

\section{e. Současná fragmentace obcí}

Dnes má Island po celém ostrově rozložených 79 municipalit (The Association of Local Authorities in Iceland 2012) s pevně vymezenými geografickými hranicemi. Největším a zároveň hlavním městem je Reykjavík. Dalšími velkými městy v islandském měřítku jsou Kópavogur, Hafnarfjörður a Akureyri (Jonsson 2002: 6). Kromě Reykjavíku, jehož populace dnes činí zhruba 115000 obyvatel, tedy 38 procent celkové populace, je v zemi pouze čtveřice měst, jejichž 
populace překračuje 10 000, a další čtyři, jejichž populace překračuje 5000 obyvatel (Local Governments 2012).

Naopak přibližně 35 municipalit má méně než 200 obyvatel (Jonsson 2002: 6). Nejmenší islandskou obcí je Árneshreppur, která má dokonce pouhých 48 obyvatel (Klimovský 2009: 184). Nesplňuje tak ani podmínku padesáti obyvatel nutnou pro existenci obce.

Značně rozvinutou je na Islandu meziobecní spolupráce, a to jak na zajišt’ování různých služeb, např́klad školství, mimo jiné skrze vytvoření spoluvlastněných agentur, tak na dobrovolné bázi v rámci nejrůznějších projektů (Structure and operation 2005: 23). Ta umožňuje mimo jiné i úsporu finančních prostředkủ. To se ukazuje být zásadní otázkou i z toho důvodu, že podíl místních správ na veřejných výdajích v posledních desetiletích rostl značnou rychlostí, a to z 22,9\% v roce 1991 na 33,3\% v roce 2001.

Ve srovnání s ostatními nordickými zeměmi je však podíl místních autorit na veřejných výdajích poměrně malý, nebot' řadu nákladných výdajů pokrývá centrální vláda. Větší role centrální vlády na Islandu v této oblasti bývá připisována velikosti a roztř́štěnému územnímu rozložení obyvatelstva (Structure and operation 2005: 22).

\section{Municipality v ČR a potenciál inspirace islandskou defragmentací}

V př̀edcházející části tohoto článku byla představena $\mathrm{z}$ historického, legislativního a administrativního hlediska situace municipalit na Islandu a způsob jejich defragmentace. Protože tato defragmentace proběhla úspěšně, nebot’ bylo dosaženo radikálního snížení počtu obcí za souběžného konsensu obyvatelstva, a navíc v období, které umožnilo poučení se z chyb dříve defragmentujících zemí, může prŕklad Islandu sloužit jako inspirativní nástroj podobných kroků v ČR, které se z ekonomického hlediska jeví být nezbytnými. Zde je nutné nicméně upozornit, že ČR se nemusí nutně inspirovat konkrétními kroky, které jsou do značné míry nepřenositelné a svébytné pro každý jednotlivý politický systém, ale spíše obecnými trendy defragmentace, např́klad navazováním meziobecní spolupráce, legislativním zakotvením ekonomické výhodnosti defragmentace či demokratickou cestou slučování formou referend místo centrálně stanoveného slučování apod. V této závěrečné části proto bude nejprve nastíněna základní struktura municipalit v ČR a na základě komparace $\mathrm{s}$ islandskou realitou poukázáno na možné způsoby inspirativnosti její defragmentací.

Veřejná správa se v České republice dělí na státní správu a samosprávu. ${ }^{5}$ Obce jako základní územní samosprávné celky provádí v souladu s principem subsidiarity správu věcí veřejných samostatně a vyšší správní orgány do jejich samostatné působnosti zasahují, jen pokud to vyžaduje ochrana zákona. Dekoncentrace státní správy, která vedla k zákonnému svěření výkonu části státní správy obcím na základě přenesené působnosti, byla rovněž provedena $\mathrm{v}$ souladu s principem subsidiarity a snahou přinést správu věcí veřejných co nejblíže občanům. Tento smíšený model veřejné správy uplatňovaný v ČR vychází ze změn po listopadu 1989, kdy bylo rozhodnuto, že reforma územní veřejné správy bude vycházet z prvorepublikových principů, nikoli z mechanismu národních výborů, který byl nastaven $\mathrm{v}$ období komunistického režimu. $\mathrm{V}$ červenci 1990 byl proto príjat ústavní zákon, oddělující státní správu a samosprávu a zavádějící samosprávu obcí, a o něco později zákon o obcích. ${ }^{6}$

\footnotetext{
${ }^{5}$ ČR má pouze dvě samosprávní úrovně - kraje a obce.

${ }^{6}$ V ČR je obecní zřízení upraveno zákonem č. 128/2000 Sb. o obcích (Obecní zřízenî) ve znění pozdějších předpisů.
} 
Zmíněné oddělení však nebylo součástí koherentního koncepčního nastavení obecního, krajského a celostátního veřejnosprávního zrrízení a s absencí takovéto koncepce se ČR potýkala v průběhu celého prvního desetiletí po pádu komunistického režimu. Až v souvislosti s přihláškou ČR do EU byla zpracována, především prostřednictvím projektu Phare „Zdokonalování veřejné správy v České republice - první fáze“, komplexnější strategie reformy veřejné správy v ČR, jež se dočkala svého schválení v roce 1999. Procesy decentralizace a dekoncentrace následně vedly po více než čtyřech desítkách let ke zrušení okresních úradů $\mathrm{k}$ poslednímu dni roku 2002. V návaznosti na jejich zrušení a nutnosti řešit problematiku výkonu jejich dosavadních kompetencí byly zrrízeny obce s rozšířenou působností, nebot' řadu dosavadních kompetencí okresních úřadů nebylo možné (kvůli jejich velikosti) svěrit obcím s pověřeným obecním úřadem. Proto bylo na základě kritéria geografického a populačního (15 tisíc obyvatel) určeno 205 obcí tohoto nového typu (MV ČR 2005). Některé dílčí pravomoci byly však přeneseny i na krajskou úroveň. Tato reforma však nesplnila zcela svůj účel nového uspořádání správy a samosprávy, nebot’ nejenže došlo k nárůstu byrokracie o minimálně $10 \%$, ale především byl fakticky zaveden trrístupňový model samosprávy, ${ }^{7}$ který s sebou nese zbytečnou finanční a administrativní náročnost, jež se odráží na efektivitě výkonu veřejné správy (Kadečka 2003: 23).

Tř́stupňový model samosprávy mimo jiné přinesl také určitý deficit odpovědnosti - obcím umožnil argumentaci, že na výkon přenesené správy nemají dostatečné ekonomické, expertní a personální zdroje, státní správě naopak, že přenosem ztratila $\mathrm{k}$ jejímu výkonu nezbytné kompetence. Zásadním ekonomickým problémem malých obcí se stala především omezená možnost využít úspor z rozsahu. Zákon o rozpočtovém určení výnosu daní ${ }^{8}$ z června 2000 měl obcím umožnit do určité míry se vypořádat s těmito ekonomickými obtížemi, nebot' zvýhodňoval větší obce, a potenciálně tak mohl vést $\mathrm{k}$ slučování obcí. Od jeho přijetí však došlo ke sloučení pouze několika desítek obcí. ${ }^{9}$

Druhou zásadní možností, kterou mají obce v ČR k optimalizaci svých ekonomických systémů a snižování finančních výdajů, je navazování spolupráce s dalšími obcemi a vzájemné rozložení finanční zátěže. Obce mezi sebou mohou spolupracovat bud’ na bilaterální, či multilaterální úrovni, na úrovni mikroregionů, svazu obcí, a dokonce je jim umožněna spolupráce i se zahraničními obcemi. Přesto tato pluralita možností spolupráce není příliš využívána, byt' obce mohou společně zakládat právnické osoby či uzavírat mezi sebou smlouvy ohledně plnění některých správních úkonů. Dnes sice je ve svazcích obcí sdruženo asi 85 \% obcí (a právě svazky obcí se ukazují být potenciálně velmi vhodným nástrojem ke sdílení nákladů při výkonu veřejné správy, a to i přenesené), ovšem tyto svazky obcí nemají př́imy z daní, a proto chybí motivace $\mathrm{k}$ jejich plodnějšímu využití, které by mohlo přecházet ve slučování. Jedním z důvodů je i to, že potenciální daňové př́jmy by musely být vzaty obcím, což by se bezpochyby setkalo s odporem. I

\footnotetext{
${ }^{7}$ Podle toho, kolik správy je na obce přeneseno, dělíme obce na tři stupně: obec I. stupně, obec s pověřeným obecním úřadem a obec s rozšířenou působností, přičemž obce II. a III. stupně zajišt'ují výkon státní správy zpravidla pro několik obcí stupně nižšího.

8 Zákon č. 243/2000 Sb. o rozpočtovém určení výnosů některých daní územním samosprávným celkům a některým státním fondům (zákon o rozpočtovém určení danî).

${ }^{9} \mathrm{~V}$ České republice mohou nové obce vznikat v zásadě trojím způsobem: oddělením části obce od stávající obce (nově vznikající obec musí disponovat samostatným katastrálním územím, minimálně tisícem obyvatel, souhlasem obyvatel nově vznikající obce potvrzeném v referendu, pokud je do 30 dnů od zveřejnění př́slušného rozhodnutí zastupitelstva podán návrh na jeho konání a schválením krajského úřadu), sloučením dvou či více stávajících obcí (předpokladem je, že spolu sousedí, že se na sloučení shodnou zastupitelstva slučujících se obcí a že tuto skutečnost s předstihem dají na vědomí př́slušnému krajskému úřadu), kdy bud’ dojde sloučením k zániku obcí a vzniku nové obce, nebo připojením, kdy přijímající obec nezaniká, nebo zánikem vojenského újezdu.
} 
proto svazky obcí spolupracují mnohem méně, než by bylo možné, a především se zdráhají podílet se na finančně náročnějších projektech, které by však v konečném důsledku mohly přinášet značné finanční úspory.

Podíváme-li se na některé prvky islandské defragmentace, musíme konstatovat, že řada jejich aspektů by na českou municipální strukturu mohla mít pozitivní dopady. Zastřešující možností je použití zkušenosti z New Public Management, které byly aplikovány i na Islandu (Manning 2001: 299). Co se partikulárních možností týče, za primární lze označit spuštění obdobné kampaně za slučování municipalit, jaká byla na Islandu spuštěna v roce 1990 (Local Governments 2012). Taková kampaň by mohla upozorňovat na skutečnost, že současná municipální struktura, vycházející z bachovských a prvorepublikových okresů, byt' prošla (nedostačujícî) reformou, nevyhovuje svými geograficko-administrativními specifiky současným potřebám výkonu samosprávy a přenesené správy.

Nastavená reforma místních samospráv a transfer služeb mezi státní a lokální strukturou, tedy mezi centrální a lokální, opět může sloužit jako inspirace. Zatímco na Islandu byly defragmentací vytvořeny místní struktury schopné efektivně plnit zákonné služby, ${ }^{10} \mathrm{v}$ ČR se tento proces nesetkal s úspěchem. Současná krajská struktura, která de facto zavedla (společně s dalšími již zmíněnými reformami) tří/pětistupňové dělení (stát, kraje, obce s rozšířenou pưsobností, obce s pověřeným úřadem, obce), je zbytečně komplikovaná, ekonomicky a administrativně zatěžující a navíc neplnící svůj účel. O tom svědčí i skutečnost, že pro potřeby EU musely být zavedeny nadkrajské regiony NUTS II, které v podstatě potvrzují chybně nastavené dělení na čtrnáct krajů. Pro ČR tak může být inspirativní dvojstupňové islandské nastavení stát - obec, případně alespoň svou redukčností, tedy např́klad stát - region (NUTS II) - obce.

Jak již bylo uvedeno, v souvislosti s převedením zodpovědnosti za základní a nižší stř̌ední školství na samosprávu v roce 1996 byla islandským obcím odpovídajícím způsobem navýšena místní daň z př́ijmu (Jonsson 2002: 8). České obce se dlouhodobě potýkají s nedostatkem př́imů, kde za jeden $z$ důvodů lze označit právě již zmiňovanou krajskou strukturu, která obcím odčerpává potenciální zdroje. Se zjednodušením správní struktury a odstraněním implicitní administrativní a navázané ekonomické zátěže by i obce měly $\mathrm{k}$ dispozici více finančních zdrojů.

Na rozdíl od Islandu v ČR chybí obdobné ustanovení jako čl. 68 Local Government Act, který centrální vládu zavazuje $\mathrm{k}$ úsilí o amalgamaci malých municipalit, $\mathrm{v}$ kooperaci s jednotlivými obcemi, Asociací místních samospráv a regionálními federacemi municipalit. Obdobně v českém právním systém chybí analogie k čl. 6 Local Government Act, který povinuje př́slušné ministerstvo $\mathrm{k}$ amalgamačním krokům, pokud počet obyvatel klesne pod padesát ve třech po sobě jdoucích letech. Lze sice chápat, že zavedení takovýchto zákonných opatření by se v ČR mohlo setkat s odporem, nebot' by oprávněně mohlo evokovat nucenou defragmentaci během komunistického režimu, která nerespektovala místní vazby, zde je ovšem nutné podotknout, že zmiňovaný čl. 6 umožňuje výjimky, pokud by amalgamace vedla $\mathrm{k}$ narušení vzájemných vazeb jak $\mathrm{v}$ rámci dané obce, tak ve vztahu $\mathrm{k}$ amalgamační obci. A Althingi vždy trval na principu, že slučování obcí musí být dobrovolné (Hovgaard, Eythórsson, Fellman 2004: 23).

Za islandský př́klad hodný následování lze označit široce rozvinutou meziobecní spolupráci (Structure and operation 2005: 23), která šetři finanční prostředky a přispívá k jejich efektivnímu vynakládání. Proč však takovéto spolupráci nejsou české obce nakloněny, mimo ekonomických

${ }^{10} \mathrm{~V}$ ČR mají obce podle zákona o obcích povinnost ve svém územním obvodu vytvářet podmínky pro uspokojování potřeb svých občanů a rozvoj sociální péče. 
důvodů, zůstává poněkud nejasné. Ekonomické zvýhodnění a legislativní podpora takové spolupráce by však z tohoto hlediska byla nepochybně př́nosná.

Z dosavadního mj. vyplývá, že samotný mechanismus defragmentace je v zásadě vedlejší otázkou. Co se ukazuje být zásadním, je motivace ke slučování. Pokud to ekonomická situace dosud nezbytně nevyžaduje (avšak finanční prostředky jsou tím přesto plýtvány), je vhodné prijímat takové kroky, které by obce ke slučování motivovaly, a to na dobrovolné bázi. Island je $\mathrm{v}$ tomto, jak bylo poukázáno, více než inspirativním př́kladem, nebot’ v tomto procesu uspěl v krátkém čase na základě všeobecného konsensu, a byla tak dosažena ekonomická, administrativní a geografická efektivita a optimalizace.

\section{Závěr}

Island prošel od 90. let 20. století procesem defragmentace, jež se zatím jeví být úspěšnou. Její průběh však dosud nebyl ukončen, a tak lze, zejména jako následek defragmentační politiky centrální vlády, očekávat další homogenizaci islandské lokální municipální struktury. Nedílnou součástí tohoto procesu jsou, jak jsme viděli, i reformy voblastech kompetencí, financí, administrativy a $\mathrm{v}$ dalších. Je rovněž posilován princip subsidiarity.

Jaké následky bude mít tato politika, ukáže až čas. Zastánci obecní fragmentace varují před ztrátou sounáležitosti s obcí. Vzhledem ke skutečnosti, že proces slučování musí být schválen v místním referendu, však lze předpokládat, že toto riziko bude menší ve srovnání se zeměmi, kde tento požadavek není př́tomen. I vzhledem $\mathrm{k}$ malé populaci jak celé země, tak jednotlivých obcí lze usuzovat, že toto riziko není nijak vysoké.

Z komparativního hlediska nabízí Island mnoho inspirujících prvků pro ty státy, které dosud neprošly procesem defragmentace, avšak z primárně ekonomických motivací lze očekávat, že se tímto procesem budou muset v blízké budoucnosti vydat. $\mathrm{Na}$ řadu těchto inspirativních prvků bylo v textu explicitně či implicitně poukázáno. Česká republika a další postkomunistické státy Evropy patří mezi množinu zemí, u nichž lze defragmentaci obecní struktury v blízké či střednědobé budoucnosti očekávat. Je zřejmé, že každý proces takto zásadního charakteru musí být přizpůsobený danému politickému systému, aby následek snahy nalézt optimálně fungující velikost sociálního systému, která by minimalizovala negativní důsledky omezených lidských schopností porozumění a řízení sociálních systémů, byla co nejpozitivnější a nejprínosnější pro dotyčné aktéry (Mitchell 2009). Existuje však pluralita prvků islandské defragmentace, především v oblasti reformy finančních a administrativních povinností a náležitostí, úpravy kompetencí, ustanovení referenda v otázce amalgamace obcí, posilování principu subsidiarity a celkové legislativní novelizace, jimiž se ČR může inspirovat.

V tomto článku jsem se $\mathrm{v}$ jeho první části soustředil na vyložení problematiky evropské defragmentace a základních tendencí a trendů, které tento proces v 2. pol. 20. století provázely. Prostřednictvím metody Qualitative Comparative Analysis jsem na základě primárně časového hlediska defragmentace vytvořil základní dichotomii mezi postkomunistickými státy a poukázal na dvojici dominantních tendencí, které v nich probíhají. Následně jsem vyložil, proč se může Česká republika inspirovat proběhlými defragmentacemi a proč Island může sloužit za vzor, jímž by se Česká republika, a potažmo další státy z dané analyzované množiny, mohly a měly inspirovat $\mathrm{v}$ procesu defragmentace, který jsem z ekonomických důvodů označil za obtížně odvratitelný. Následně jsem se zaměřil na aspekty úspěšné a dosud probíhající islandské defragmentace. Na pozadí legislativních změn a praktických problémů jsem poukázal na úskalí 
defragmentace, a to od jejího začátku do jejího současného, dosud probíhajícího stavu. V závěru jsem na základě stručného představení základní problematiky municipální struktury v České republice poukázal na aspekty islandské defragmentace, které mohou sloužit jako modelový př́ípad pro analýzu těchto jevů, které v Evropě probíhaly v druhé polovině 20. století a v mnoha př́padech ještě probíhají, a zároveň mohou být inspirativním zdrojem informací pro vytváření budoucích policy.

\section{Literatura a zdroje}

Aalborgská charta (1984).: Charta evropských měst a obcí směřujících $\mathrm{k}$ trvale udržitelnému rozvoji, Dánsko, Aalborg.

Baldersheim, H. Stahlberg, K. (c1994). Towards the self-regulating municipality: free communes and administrative modernization in Scandinavia, Ashgate, Aldershot.

Beveridge, W. H. (1942). Social Insurance and Allied Services. Dostupné on-line: http://news.bbc.co.uk/2/shared/bsp/hi/pdfs/19_07_05_beveridge.pdf, [cit. 30. 10. 2012].

Bogason, P. (1996). New modes of local political organizing: local government fragmentation in Scandinavia, Commack, Nova Science Publishers.

CEMAT (1983). Evropská charta regionálního a prostorového plánování. Španělsko, Torremolinos.

Cohen, B. (2006). Urbanization in developing countries: Current trends, future projections, and key challenges for sustainability. Technology in Society 28, s. 63-80.

UCLG (2008). Decentralization and local democracy in the world: First Global Report by United Cities and Local Governments, Barcelona, GRALE. Dostupné on-line:

http://issuu.com/uclgcglu/docs/gold_report_en/9\#print

Fekete, É. et al (2002). Size of Local Governments, Local Democracy and Local Service Delivery in Hungary. In Consolidation or Fragmentation? The Size of Local Governments in Central and Eastern Europe (ed. Swianiewicz, P.), Budapest, OSI/LGI.

Hermenier, H. [2008]: Balancing Democracy, Identity and Efficiency: Changes in local and regional structures in Europe, Brusel, Paříž, CCRE, CEMR. Dostupné online:

http://www.ccre.org/docs/changes_in_local_and_regional_structures_web_EN.pdf, [cit. 09. 12. 2012].

Hovgaard, G., Eythórsson, G. T., Fellman, K. (2004). Future Challenges to Small Municipalities: The Cases of Iceland, Faroe Islands and Åland Islands, Stockholm, Nordregio.

Iceland (1998). Local Government Act: Island. Dostupné on-line:

http://www.samband.is/media/enska/Local-Government-Act-no-45-1998-with-subsequentamendments.pdf), [cit. 12. 10. 2012].

Iceland (2010). Iceland: Basic Facts. Dostupné on-line: http://www.iceland.is/country-and-nature/basicfacts), [cit. 5. 5. 2010].

Jóhannesson, H. (2007). An Overview of Rural Development in Iceland In: Continuity or

Transformation?: Perspectives on Rural Development in the Nordic Countries. Edited by Andrew K. Copus, Stockholm, Nordregio. Dostupné on-line:

http://www.rha.is/static/files/Rannsoknir/2007/Continuity-transformation_Rural-

Norden.pdf\#page=149, [cit. 3. 4. 2013].

Jonsson, S. (2002). Local government in Iceland. Reykjavik, The Association of Local Authorities in Iceland. Dostupné on-line: http:/ /www.samband.is/ files/\%7B2a964a70-339b-4bc2-8a59-

57a3940f91d9\%7D_local\%20government\%20in\%20iceland.pdf, [cit. 5. 5. 2010].

Jüptner, P. (2010). Přednášky kurzu Evropská komunální politika, Praha, IPS UK FSV. 
Jüptner, P., Polinec, M., Švec, K. et al. (2007). Evropská lokální politika 2, Praha, IPS UK FSV. Kadečka, S. (2003). Právo obcí a krajů v České republice, Praha, C. H. Beck.

Kersting, N., Vetter, A. (2003). Reforming local government in Europ: closing the gap between democracy and efficiency, Opladen, Leske + Budrich.

Klimovský, D. (2009). O možných riešeniach fragmentovanej lokálnej sídelnej struktury. Acta Politologica 1 (2), s. 182-213.

Klimovský, D. (2010). Konsolidačné reformy a decentralizácia v európskych podmienkach. Acta Politologica 2 (3), s. 86-96.

Law, G. (2003-2012). Statoids: Administrative Divisions of Countries. Dostupné on-line: http://statoids.com/. [cit. 07. 12. 2012].

Majerová, V. (2008). Sociologie venkova a zemědělství, Praha, ČZU.

Manning, N. (2001). The legacy of the New Public Management in developing countries. International Review of Administrative Sciences 67, s. 297-312. DOI: 10.1177/0020852301672009

Mitchell, M. (2009). Complexity a guided tour adaptive systems, Oxford, Oxford University Press. MV ČR (2005). Veřejná správa v České republice, Praha, MV ČR.

Nordal, J., Kristinsson, V. (1996, ed.). Iceland - The Republic, Reykjavik Central Bank of Iceland.

Norton, A. (1994). International Handbook of Local and Regional Government, Aldershot, Edward Elgar.

Pfeil, E. S. (2010). Hungarian Public Service Reform: Multipurpose Microregional Associations. In Consolidation or Fragmentation? The Size of Local Governments in Central and Eastern Europe (ed. Swianiewicz, P.), Budapest, OSI/LGI.

Provazníková, R. (2009). Financování měst, obcí a regionů: teorie a praxe, Praha, Grada Publishing.

Reynarsson, B. (1999). The Planning of Reykjavik, Iceland: Three ideological waves. A historical overview. Planning Perspectives 14, s. 49-67. Dostupné on-line: https://borg.hi.is/pir.rtf, [cit. 3. 4. 2013]. DOI: $10.1080 / 026654399364346$

Rada Evropy (2005). Structure and operation of local and regional democracy. Dostupné on-line: http://eng.felagsmalaraduneyti.is/media/kosningar2006/Local_Regional_Demo_Ice_2005.PDF, [cit. 16. 11. 2012].

The Association of Local Authorities in Iceland (2012). Municipalities and Unification of municipalities in Iceland since 1950. Dostupné on-line:

http://www.samband.is/files/1423886735sameining\%20sveitarfelaga\%201950-2010_Engl.doc, [cit. 19. 11. 2012].

Tönnies, F. (1955). Community and Association: Gemeinschaft und Gesellschaft, London, Routledge \& Kegan Paul.

Vilhjalmsson, V. T., (2005): Local government in Iceland. [Reykjavik], [The Association of Local Authorities in Iceland], Prezentace Powerpoint. Dostupné on-line: http://www.gpiatlantic.org/conference/reports/iceland.ppt, [cit. 19. 11. 2012].

Wollmann, H., Lankina, T. (2003). Local Government in Poland and Hungary. In Local Democracy in Post-Communist Europe (eds. Baldersheim, H. Illner, M., Wollmann, H.). Leske + Budrich, Opladen, s. 91-123.

Zákon č. 128/2000 Sb. o obcích (Obecní zríizenî) ve znění pozdějších předpisů.

Zákon č. 243/2000 Sb. o rozpočtovém určení výnosů některých daní územním samosprávným celkům a některým státním fondům (zákon o rozpočtovém určení danî). 
Tomáš Váňa: Procesy evropské defragmentace jako inspirativní nástroj policymaking

\section{Processes of European defragmentation as an inspirative tool for policymaking}

\section{SUMMARY}

This paper looks at the different stages of European municipal defragmentation and at the diverse models that post-war countries adopted for their municipal structures. It suggests that apart from the legislative, identity or economic approach to the study of municipal defragmentation, its time aspect, which has until now escaped interest in the given discourse, can offer an inspiring insight into the given question. The text thus distinguishes between (i) countries which defragmented their municipal structures at an early stage, (ii) countries which defragmented recently, (iii) countries which underwent defragmentation in both of the identified periods, (iv) countries where defragmentation didn't take place, (v) former countries of the Eastern bloc which underwent defragmentation and after their transition to democracy underwent a reverse process, and (vi) former countries of the Eastern bloc which underwent defragmentation and after their transition to democracy continued with the defragmentation process.

The paper notes that municipal defragmentation was, in a number of countries, undertaken with little previous knowledge regarding the possible impacts of the different approaches which these individual countries chose. It further looks at the problems which countries that underwent defragmentation at an early stage had to face and points out that countries that defragmented recently had a comparative advantage because they could learn from these countries' errors. It identifies two countries of this sort Germany and Iceland - and concentrates on the latter case, analysing its defragmentation process as a case study, pointing out the positive aspects of this defragmentation process and concluding it to be a successful one. It understands Icelandic defragmentation to be successful, because the reduction in the number of municipalities was not only substantial, but it was moreover achieved with the consensus of the population. In this sense the consensual aspect of defragmentation is understood to be key, because while the number of municipalities was reduced in countries of the former Eastern bloc as well, this was not achieved in a democratic or consensual way, which, in a number of cases, led to the reverse process of fragmentation after the dissolution of the bloc and the fall of authoritarian regimes.

The paper sets Icelandic defragmentation into a wider context by analysing the historical, economic, legislative, municipal, functional and structural evolution of the different Icelandic societal and state subsystems, trying, through this insight, to distinguish traces of Iceland's more recent success in municipal defragmentation.

Through applying the QCA method of analysis, the paper looks at common and distinct features of the different approaches to municipal defragmentation and draws a sharp dichotomy between defragmentation trends in post-communist countries and those in countries of the Western bloc. By showing that there are trends inherent to post-communist political systems, this paper presents the idea that these systems can learn from errors made by countries that underwent defragmentation before them. Drawing on the example of the late-defragmenting Iceland, the paper shows how currently or prospectively defragmenting countries can learn from its experience.

The suggestions in the last part of the paper are applied to the case of the Czech Republic and to possible measures which it could undertake by learning from the Icelandic experience. Primarily the New Public Management approach could be applied. A supplementary suggestion is to launch a campaign in favour of the defragmentation of municipalities, in order to promote the idea among the countries' citizens and thus to increase the prospect of any such process being undertaken in a consensual manner. Such a campaign could emphasize the fact that the current municipal structure of the Czech Republic, 
based on the Bach and First Republic structure, does not, even after the structural reform which it underwent, meet the current requirements of current public administration, not only from a geographical, but also from an administrative and economic point of view. Reform of the different competences, obligations and liabilities of the different public administrative bodies, mainly on the vertical axis, is suggested as desirable. Reform of the financial and, in general, economic dimension of public administration is also identified as necessary, and it is suggested that defragmentation could prove to be beneficial in this respect, as transfer and volume costs could be reduced. A legislative point analogical to article 68 of the Icelandic Local Government Act, which obliges the central government to amalgamate municipalities if the number of inhabitants within a municipality falls below fifty, is also identified as potentially beneficial, although its risks, mainly a decrease in the level of consensus, are recognized. Other measures inspired by the Icelandic example are suggested as well, particularly those concerning democratic referendums, legislative and economic incentives, and municipal cooperation. The mutual cooperation of diverse municipalities (not only at national but also at supranational level) is also suggested as a favourable policy, providing opportunities to learn from the exchange of good practice and thereby to reduce costs. 